\title{
Review
}

\section{Promoting Social Capital by Expanding the Conception of Giftedness}

\author{
Joseph S. Renzulli ${ }^{1}$ \\ "The good we secure for ourselves is precarious and uncertain until \\ it is secured for all of us and incorporated into our common life." \\ Jane Addams
}

\begin{abstract}
Changing the World... One Life at a Time
After repeatedly observing the little boy crying on the school bus, Melanie, a fifth grade student, took a seat next to him and struck up a conversation. "You don't understand," said Tony, a first grader whose face was practically hidden behind the thickest eyeglasses Melanie had ever seen. "You see these glasses? I'm partially sighted. The kids trip me and make fun of me; I have special books for my subjects, but there are no books in the library that I can read. "Later that day Melanie approached her enrichment teacher and asked if she could make Tony her "Type III" Project [Type III Enrichment in The Enrichment Triad Model (Renzulli, 1977, p.22) is a self-selected individual or small group investigation of a real problem] for the year. Over the next several days, Melanie and the enrichment teacher drew up a plan that began with some "friendly persuasion" for the boys that were harassing Tony. A few of the school's bigger, well-respected boys and girls escorted him from the school bus and sat with him in the lunchroom. Melanie then asked Tony a series of questions from an instrument called the Interest-A-Lyzer to determine what some of his reading interests might be. She recruited a number of the school's best writers to work on large print "big books" that dealt with Tony's interests in sports and adventure stories. She also recruited the school's best artists to illustrate the books, and served as the editor and production manager for the series. As the project progressed over the next several months, a remarkable change took place in Tony's attitude toward school. He became a local celebrity, and other students even signed out books from Tony's special section of the library. Melanie's creative idea and her task commitment resulted in the development of profound empathy and sensitivity to human concerns and the application of her talents to an unselfish cause. When questioned about her work, Melanie explained simply, "It didn't change the world, but it changed the world of one little boy."
\end{abstract}

\section{Background}

In the early 1970s I began work on a conception of giftedness that challenged the traditional view of this concept as mainly a function of high scores on intelligence tests. This work was greeted by a less than enthusiastic reception from the gifted establishment of the time including rejections of my writing by all the main journals in the field of gifted education. My convictions about a broadened view of human potential caused me to seek an audience elsewhere, and in 1978 the Kappan published my article entitled, What Makes Giftedness: Reexamining a Definition (Renzulli, 1978).

\footnotetext{
${ }^{1}$ Corresponding author, Prof., Director, The National Research Center on the Gifted and Talented, The Neag School of Education, University of Connecticut, USA; joseph.renzulli@uconn.edu, ORCID: 0000-0002-5370-9633

(C) Talent; ISSN 2717-7122 http://talentjournal.net
} 
In the ensuing years scholars, practitioners, and policy makers began to gain a more flexible attitude toward the meaning of this complex phenomenon called giftedness, and the 1978 Kappan article is now the most widely cited publication in the field. I mention this fortunate turn of events mainly to call attention to the always expectant hope that people can change their minds about a long cherished belief; and to acknowledge the courage of Robert Cole, the Kappan editor, who was willing to take a chance on what was at the time a decidedly unpopular point of view.

In what is now popularly known as the three-ring conception of giftedness (above average but not necessarily superior ability, creativity, and task commitment), I embedded the three rings in a hounds tooth background that represents the interactions between personality and environment (see Figure 1). These factors aid in the development of three clusters of traits that represent gifted behaviors. What I recognized but did not emphasize at the time was that a scientific examination of a more focused set of background components is necessary in order for us to understand the sources of gifted behaviors and more importantly, the ways in which people transform their gifted assets into constructive action [Note: I prefer to use the word, "gifted," as an adjective rather than a noun]. Why did Melanie devote her time and energy to a socially responsible project that would improve the life of one little boy? And can a better understanding of people who use their gifts in socially constructive ways help us create conditions that expand the number of people who contribute to the growth of social as well as economic capital? Can our education system produce future corporate leaders who are as sensitive to aesthetic and environmental concerns as they are to the corporate bottom line? Can we influence the ethics and morality of future industrial and political leaders so that they place gross national happiness on an equal or higher scale of values than gross national product? These are some of the questions we are attempting to address in an ongoing series of research studies that examine the relationship between non-cognitive personal characteristics and the role that these characteristics play in the development of social capital.

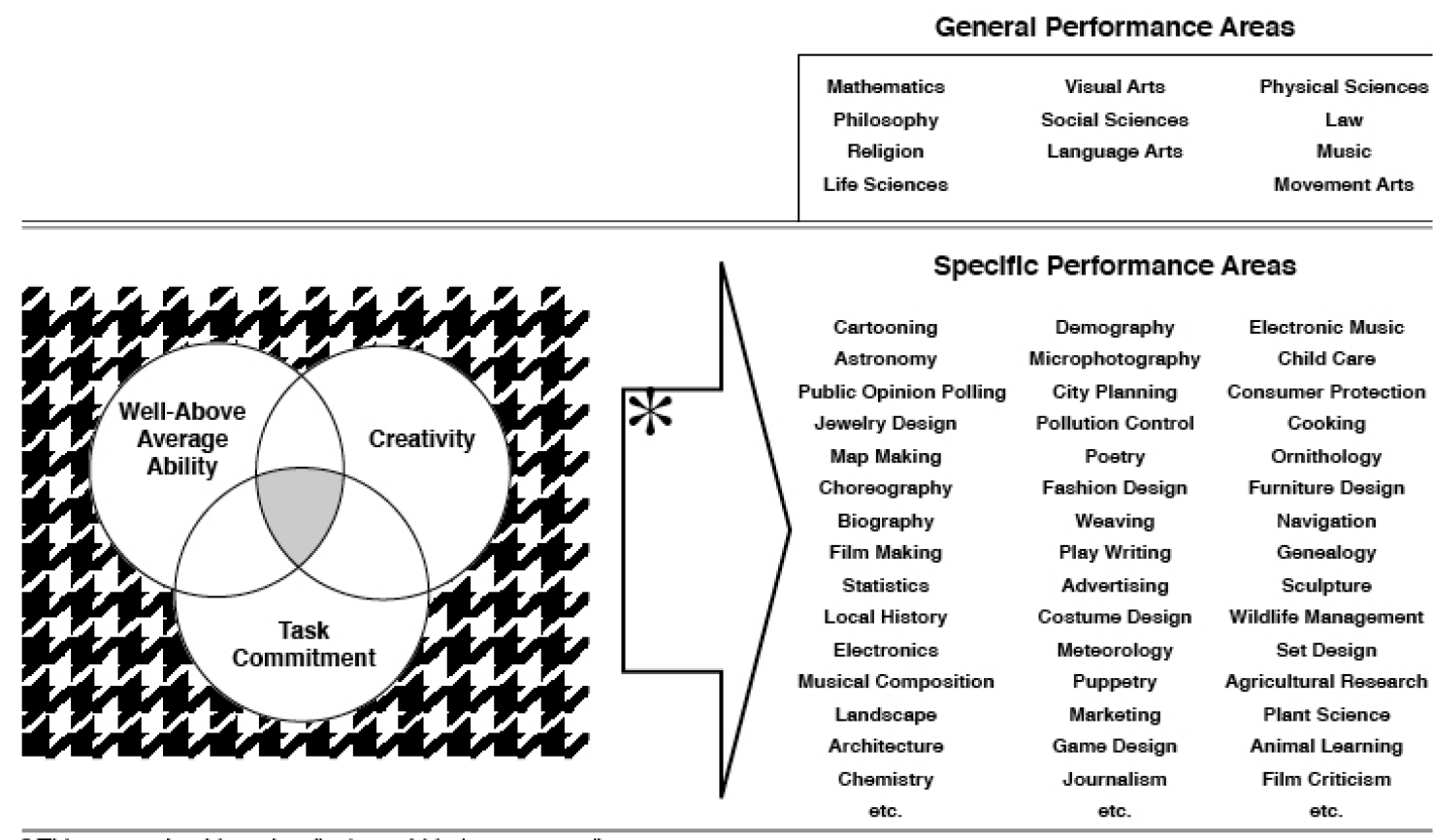

${ }^{\star}$ This arrow should read as "... brought to bear upon ..."

Figure 1. The Three Ring Conception of Giftedness 


\section{What Is Social Capital and Why Is It Important?}

Financial and intellectual capital are the well-known forces that drive the economy and result in generating highly valued material assets, wealth production, and professional advancement all important goals in a capitalistic economic system. Social capital, on the other hand, is a set of intangible assets that address the collective needs and problems of other individuals and our communities at large. Although social capital cannot be defined as precisely as corporate earnings or gross domestic product, Labonte (1999) eloquently defines it as: "something going on 'out there' in peoples day-to-day relationships that is an important determinant to the quality of their lives, if not society's healthy functioning. It is the 'gluey stuff' that binds individuals to groups, groups to organizations, citizens to societies" (p. 431). This kind of capital generally enhances community life and the network of obligations we have to one another. Investments in social capital benefit society as a whole because they help to create the values, norms, networks and social trust that facilitate coordination and cooperation geared toward the greater public good.

Striking evidence indicates a marked decline in American social capital over the latter half of the century just ending. National surveys show declines over the last few decades in voter turnout and political participation, membership in service clubs, church-related groups, parent-teacher associations, unions, and fraternal groups. For example, membership in the League of Women Voters has decreased by 42 percent since 1969 and an even greater decrease (59 percent) has been recorded for the Federation of Women's Clubs. Similar reductions are found in volunteerism to organizations such as the Red Cross and Boy Scouts, and to service and fraternal groups such as the Jaycees, the Elks, the Lions, and the Masons (Putnam, 1995). These declines in civic and social participation have been paralleled by an increasing tendency for young people to focus on narrow professional success and individual economic gain.

What is perhaps most striking when examining the commentary of leading scholars about the differences between economic and social capital is that investments in both types of national assets can result in greater prosperity and improved physical and mental health as well as a society that honors freedom, happiness, justice, civic participation, and the dignity of a diverse population. Putnam $(1993,1995)$ pointed out that the aggregation of social capital has contributed to economic development. He found that widespread participation in group activities, social trust, and cooperation created conditions for both good government and prosperity. Putnam traced the roots of investments in social capital to medieval times and concluded that communities did not become civil because they were rich, but rather they became rich because they were civil. "Researchers in such fields as education, urban poverty, unemployment, the control of crime and drug abuse, and even health have discovered that successful outcomes are more likely in civically engaged communities" (Putnam, 1995, p. 66). Other researchers have concluded that social capital is simultaneously a cause and an effect leading to positive outcomes such as economic development, good government, reduced crime, greater participation in civic activities, and cooperation among diverse members of a community. (Portes, 1998).

Researchers who have studied social capital have examined it mainly in terms of its impact on communities at large, but they also point out that it is created largely by the actions of individuals. 
They also have reported that leadership is a necessary condition for the creation of social capital. Although numerous studies and a great deal of commentary about leadership have been discussed in the gifted education literature, no one has yet examined the relationship between the characteristics of gifted leaders and their motivation to use their gifts for the production of social capital.

\section{Gifted Education and Social Capital}

Research on the characteristics of gifted individuals has addressed the question: What causes some people to use their intellectual, motivational, and creative assets in ways that lead to outstanding manifestations of creative productivity, while others with similar or perhaps even more considerable assets fail to achieve high levels of accomplishment? Perhaps an even more important question so far as the production of social capital is concerned is: What causes some people to mobilize their interpersonal, political, ethical, and moral realms of being in such ways that they place human concerns and the common good above materialism, ego enhancement, and self-indulgence? How can we understand the science of human strengths that brings about the remarkable contributions of people like Nelson Mandela, Rachel Carson, Mother Theresa, and others who have focused their talents on bringing about changes that are directed toward making the lives of all people better?

The folk wisdom, research literature, and biographical and anecdotal accounts about creativity and giftedness are nothing short of mind boggling; and yet, we are still unable to answer these fundamental questions about persons who have devoted their lives to improving the human condition. Several writers (Gagné, 1985; Gardner, 1983; Mönks, 1991; Renzulli, 1978; Sternberg \& Davidson, 1986; Tannenbaum, 1986) have speculated about the necessary ingredients for giftedness and creative productivity. These theories have called attention to important components and conditions for high level accomplishment, but they fail to explain how the confluence of desirable traits result in commitments for making the lives of all people more rewarding, environmentally safe, peaceful, and politically free. Concern for a psychology that focuses on these positive human concerns is especially important because it will help give direction to the educational and environmental experiences we might be able to provide for the potentially gifted and talented young people who will shape both the values and the actions of the new century.

That certain ingredients are necessary for creative productivity is not debatable; however, the specific traits, the extent to which they exist, and the ways they interact with one another will continue to be the basis for future theorizing, research, and controversy. We need to learn more about all aspects of trait theory, but I also believe that new research must begin to focus on that elusive "thing" that is left over when everything explainable has been explained. This "thing" is the true mystery of our common interest in human potential, but it also might hold the key to both explaining and nurturing that kind of genius that has been applied to the betterment of mankind.

\section{Operation Houndstooth}

One of the more fortunate new directions in the social sciences in recent years has been the development of the positive psychology movement. Championed by Martin E. P. Seligmen, this movement focuses on enhancing what is good in life rather than fixing what is maladaptive behavior. 
The goal of positive psychology is to create a science of human strengths that will help us to understand and learn how to foster socially constructive virtues in young people. Although all of society's institutions need to be involved in helping to shape positive values and virtues, schools play an especially important part today because of changes in family structures and because people of all ages now spend more than a fifth of their lives in some kind of schooling. In a research study dealing with developing excellence in young people, Larson (2000) found that average students report being bored about one-third of the time. He speculates that participation in civic and socially engaging activities might hold the key to overcoming some of the disengagement and disaffection that is rampant among American youth. Larson argues that components of positive development such as initiative, creativity, leadership, altruism, and civic engagement can result from early and continuous opportunities to participate in experiences that promote characteristics associated with the production of social capital.

This article examines the scientific research that defines several categories of personal characteristics found in the hounds tooth background underlying the three ring conception of giftedness. Collectively referred to as Operation Houndstooth, these categories include, but may not be limited to: Optimism, Courage, Romance with a Topic or Discipline, Sensitivity to Human Concerns, Physical/Mental Energy, and Vision/Sense of Destiny. Empirical research and anecdotal exemplars of adults and young people who have displayed these concerns will be described, present research studies and instrument development initiatives will be reported, and an agenda for programmatic research that hopefully will lead to a better understanding of positive human concerns will be discussed. Finally, suggestions will be made regarding how parents, schools, and the society at large might take a more active part in providing opportunities, resources, and encouragement for participation in experiences that promote the kinds of positive human concerns that are the raw material of increased social capital.

The positive psychology movement, coupled with my continuing fascination about the scientific components that give rise to socially constructive giftedness, has resulted in an examination of personal attributes that form the framework of Operation Houndstooth. A comprehensive review of the literature and a series of Delphi technique classification studies led to the development of an organizational plan for studying the six components and thirteen subcomponents presented in Figure 2. I will refer to these traits as co-cognitive factors because they interact with and enhance the cognitive traits that we ordinarily associate with the development of human abilities. Moon (2000) suggests that constructs of this type, including social, emotional, and inter/intra-personal intelligence are related to each other and are independent from traditional measures of ability. The twodirectional arrows in this diagram are intended to point out the many interactions that take place between and among the Houndstooth components.

Before discussing the Houndstooth components it is important to point out that we are in the early stages of trying to understand a very complex concept. Quick and easy answers about promoting larger amounts of social capital as a national goal may be years away, but it is my hope that this article will motivate other investigators to sense the importance of this challenge and pursue studies that will contribute to our understanding of this complex concept. It is also my hope that school personnel will begin to think about steps that they can take now to make changes in the ways we 
promote in young people some of the virtues discussed below. And earlier is better! Howard Gardner has commented on the importance of early experiences in acquiring enduring habits of mind: "Research shows that when children are young they develop what you call intuitive theories. It's like powerful engravings on your brain. Teachers don't realize how powerful they are, but early theories don't disappear, they stay on the ground" (Gardner quoted in Kogan, 2000, p. 66). Wouldn't it be nice if we began engravings that might lead to societal improvements rather than the status and materialism markers so prevalent in the life styles of many of our young people?

\section{Intelligences Outside The Normal Curve OPERATION HOUNDSTOOTH}

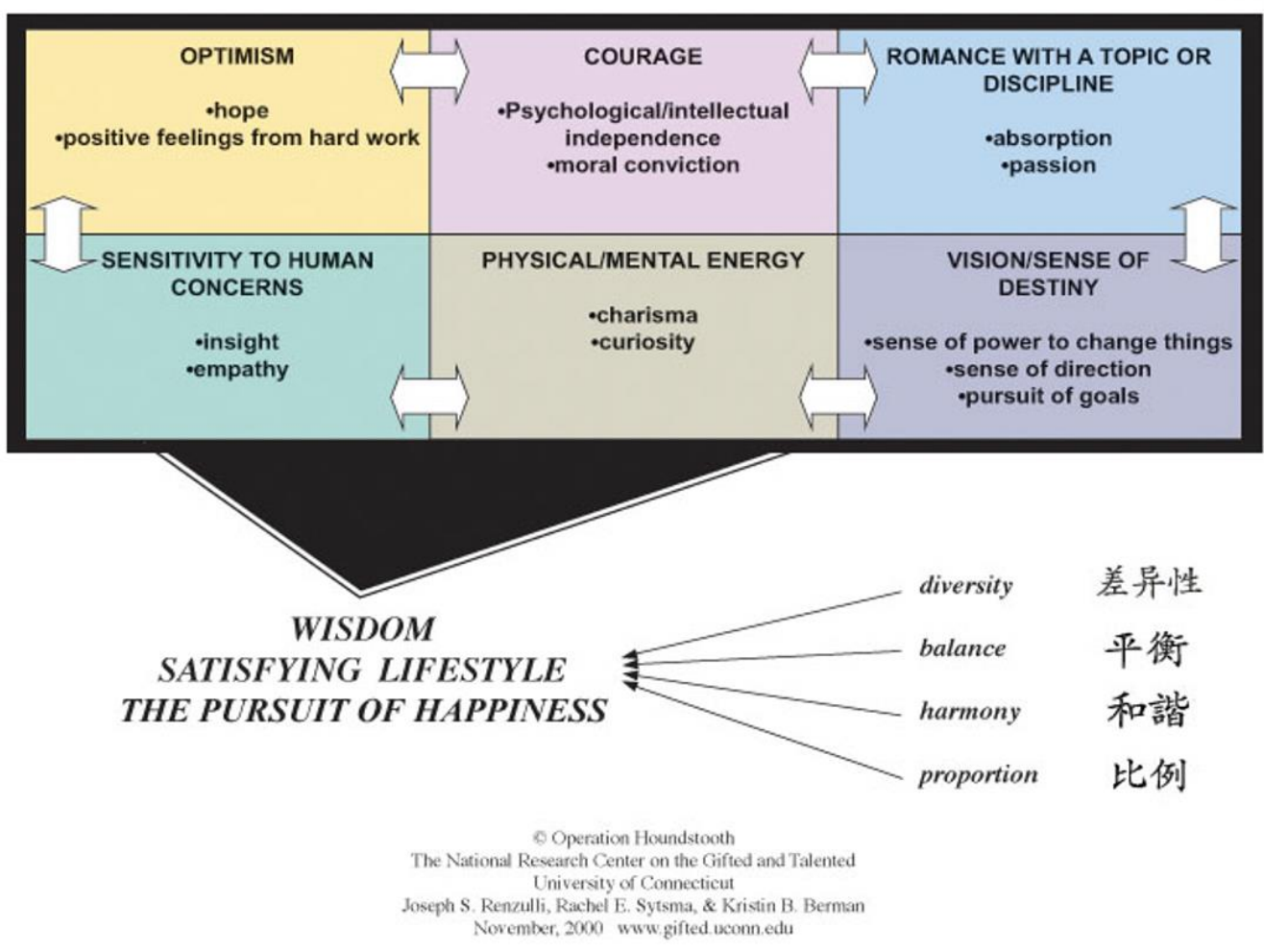

Figure 2. Intelligences outside the Normal Curve

Thus, the goals of Operation Houndstooth are twofold. First, we examine the scientific research that has been conducted on the components in Figure 2. This phase includes clarifying definitions and identifying, adapting, and constructing assessment procedures that will help us to extend our understanding of the components, especially in young people. A major assumption underlying this project is that all of the components defined in our background research are subject to modification. Thus, the second phase consists of a series of experimental studies to determine how various school-related interventions can promote the types of behavior defined within the respective components. These interventions will draw upon existing and newly developed techniques that can be used within various school and extracurricular contexts. 


\section{Optimism}

The most widely investigated Houndstooth component is optimism. The advent of positive psychology and multi-dimensional research approaches to health and wellness, have created an environment ripe for the resurgence of research on optimism. Although difficult to define with absolute parameters, Peterson (2000) describes it as an amoeba-like, "velcro" concept to which everything seems to stick for reasons that are not entirely obvious. The reason for optimism's amoebic and adhesive nature is its complexity. Peterson encourages a shift from a purely cognitive approach toward conceptualizing optimism as a cognitive characteristic with strong emotional and motivational overtones. Culture appears pivotal in that social values influence individuals, and individual differences in the measurement of optimism are prominent within positive social science research. As we move forward with experiments to promote optimism, this observation reminds us that opportunities should be sought to capitalize on the cultural strengths of diverse groups.

Current researchers have investigated the effects of optimism in a variety of contexts ranging from medicine and psychotherapy to the home, the office, and the classroom (Aspinwall \& Richter, 1999; Chang, 2001; Fredrickson, 2000; George \& Scheft, 1998; Peterson, 2000; Scheier \& Carver, 1985; Seligman, 1991; Stipek, Lamb, \& Zigler, 1981; Tiger, 1979). The best current understanding of optimism is that it is a mood or attitude associated with an expectation about a future that one regards as socially desirable - either to the individual's advantage or for the individual's pleasure (Tiger, 1979).

Optimism appears to have evolutionary benefits (Tiger, 1979) and is susceptible to alteration. Imagine optimism as a rooted tree and human nature as the soil. The soil holds the seed and enables initial development of the tree. In the right conditions, with the right nutrients, that tree will grow larger. On the other hand, if conditions are counterproductive or even less than favorable, the tree will wither and die. Optimism is something we all have to a certain degree; it is a personal, dispositional trait that appears to mediate between external events and individual interpretation of those events (Seligman \& Csikszentmihalyi, 2000). Yet, work by Seligman and his colleagues (1991, 1995) have illustrated those optimistic behaviors or mindsets can be modified (learned) through reflective self-awareness and intervention strategies. Aspinwall and Brunhart (2000) note that while optimism may be based on one's sense of competence or learned ways of coping, it may also be rooted in a variety of beliefs in powers that transcend the individual, such as spiritual or religious beliefs. In fact, Lionel Tiger, in his book, Optimism: The Biology of Hope, (1979), argues that religions may have arisen in response to people's biological need to be optimistic. Beliefs in powers outside the self are quite personal and are culturally as well as individually variable.

Given the state of affairs in combination with ample literature explaining optimism's positive benefits to well-being, coping, perseverance, health, and happiness, it is essential that we expand our understanding of the power of optimism in the development of talent. It is difficult to maximize an individual's potential when hampered by physical disorders, depleted energy levels, and negative attitudes and expectations, let alone if one is ill equipped at coping and has difficulty persevering. Perhaps those students with high measures of optimism in combination with other co- 
cognitive factors presented in this article are the very students most likely to develop into the creative producers and eminent leaders, of tomorrow.

\section{Courage}

The factor of courage has been described in various contexts. Physical courage, facing physical danger; psychological courage, facing one's own irrational fear; and moral courage, maintaining moral integrity while overcoming the fear of being rejected by the group (Putman, 1997). Moral courage is strongly correlated with other Houndstooth factors such as empathy, altruism, and sensitivity to human concerns. The concept of sensitivity to human concerns combines these concepts into action in that through heartfelt feeling for another's plight, one will act courageously for the benefit of others, even in the face of societal disapproval.

Courage has also been discussed in connection with the emergence of creativity, so much so that MacKinnon (1978) recognized it as the most significant characteristic of a creative person. This includes questioning what's accepted, being open to new experiences, listening to one's own intuition, imagining the impossible, and standing aside, or against, the group if necessary. Berman (1997) agrees with MacKinnon, pointing out that the job of teachers is not so much to teach traits such as courage, but rather to model them. Berman's work deals with the development of prosocial behaviors inherent in growth of moral courage. His work reflects a body of literature that documents the early natural ability of children to feel empathic towards others and at very early ages (Gove \& Keating, 1979; Zahn-Waxler \& Radke-Yarrow, 1982).

Often the creative person must grapple with internal blocks or fears that must be overcome in order to seek and express the truths of new ideas, popular or not. Nicolaus Copernicus drew on great psychological courage to resist the overwhelming sense of perception and tradition that told men of his time how the sun rises and sets. As the individual power of his mind began to discover the illusion of the popular thinking, he struggled with the conflict between his pious religious faith and the truth of his profound discovery. He found solace for his seemingly heretical thinking in the very faith that posed his conflict: "...All I can do is to adore when I behold this unfailing regularity, this miraculous balance and perfect adaptation. The majesty of it all humbles me to the dust (Barns, 1979, p. 112)." This man, along with those who followed his lead -Kepler, Bruno, and Galileo - exemplified great psychological courage in pursuit of the truth.

Many people are blocked when they find themselves in psychological servitude, or under the emotional manipulation of another being. Psychological courage must be developed to live a normal life of individuating from parents and developing healthy relationships that do not interfere with independent functioning. A strong basis of psychological courage is necessary for making good decisions that establish positive conditions for the productive functioning of the individual rather than decisions based in denial of problems or for instant gratification (Putman, 2000). Education for moral and physical courage is more common in our culture than training in psychological courage. The growth of psychological courage lies more deeply in an understanding of positive human development, and is fundamental to the development of the other kinds of courage (Putman, 1997). 


\section{Romance with a Topic or Discipline}

The concept of romance with a topic can be explored through the notions of passion, peak experience, or flow. This relates to physical and mental energy in that intrinsic motivation exists in the context of topics that have appeal or ones that arise from personal interest (Ryan \& Deci, 2000). When all of these elements are present, the original meaning of the word passion becomes relevant. The Latin root of the word is pati, meaning to suffer. One is willing to suffer for that which one loves. The concept of suffering also implies the connection with effort, exertion, and intense action (Kaufman, 2000).

Passion has stimulated interest among philosophers and poets for millennia. The connection to the creative spirit has always been a target of inquiry in Socrates' writings:

There is a ... form of madness or possession of which the Muses are the source. This seizes a tender, virgin soul and stimulates it to rapt, passionate expression ... glorifying the countless glorious deeds of ancient times for the instruction of posterity (Eliot, 1909, Vol. 7, p. 422).

And from the work of Burke in the 1700s:

The passion . . . is that state of the soul, in which all its motions are suspended ... in this case the mind is so entirely filled with its object that it cannot contain any other (Eliot, 1909, Vol. 24, p. 47).

This description precedes the theory of flow as described by Csikszentmilhalyi (1990). When one becomes thoroughly engaged in an activity in which the balance of ability and challenge meshes, the resulting experience is one of total absorption and self- actualization. In Csikszentmilhalyi's research (1996), participants' activities stimulated the feeling of flow were often "painful, risky, difficult activities that stretched the person's capacity and involved an element of novelty and discovery" (p.110). The activity became almost automatic yet with a high focus of consciousness. This state is also represented in the highest order of Maslow's hierarchy of basic needs (Maslow, 1954). Human beings are motivated to reach the highest level of self-actualization finding a nearly spiritual satisfaction in activity.

In the study of creative and eminent adults, the love of a topic has usually begun at an early age and blossomed under nurturing circumstances. Talent, personality and ability are often not enough to succeed without the ingredient of the labor of love (Amabile, 1983). Popular wisdom encourages counselors of young people to advise them to do what they love, yet we may need to go beyond this traditional advice. Without emphasis also on the difficulty and sometimes pain of achievement, and an acknowledgement of the darker emotions of fear, anxiety, disillusionment and rage that are part of real passions along with strategies to cope with this part of the passionate experience, the concept of romance with a topic becomes only a romantic fantasy (Kaufman, 2000). 


\section{Sensitivity to Human Concerns}

Sensitivity to human concerns deals with the concept of moral courage and its correlates of empathy and altruism. The roots of these words give a universal basis for their definition: empathy (Greek, pathos - feeling), altruism (Latin, alter - other). The concept of sensitivity to human concerns combines these concepts into action in that through heartfelt feeling for another's plight, one will act, even in the face of societal disapproval, for the benefit of others. Berman's (1997) work deals with the development of prosocial behavior, which encompasses the development of empathy, altruism, and sensitivity to human concerns. His work echoes a body of literature that documents the early natural ability of children to feel empathic towards others and at very early ages (Gove \& Keating, 1979; Zahn-Waxler \& Radke-Yarrow, 1982).

Instruments to measure empathy have been developed (Chlopan, McCain, Carbonell \& Hagen, 1985; Feshback, \& Hoffman, 1978). A meta-analysis of studies in the relationship between empathy and prosocial behavior shows inconsistent results in the relationship, but generally finds the strength of the association to increase with age. Inconsistencies can be a result of various methods of assessment. (Underwood \& Moore, 1982) Implications lead to the question of whether these traits can be influenced by environment, or more importantly, can we teach sensitivity? Danish and Kagan (1971) found significant changes on the Scale of Affective Sensitivity in a control group after an intensive counseling intervention.

Other researchers have found a relationship between empathic or altruistic tendencies and helping behaviors (Eisenberg \& Miller, 1987; Eisenberg-Berg, 1979; Mehrabian \& Epstein, 1972; Reis, 1995). This connection suggests the importance of developing ways to increase empathic tendencies if sensitivity to human concerns is a trait of value. This appears particularly important in our current climate as a number of studies have pointed to a decrease in knowledge and caring about social concerns among young people (Fowler, 1990; Hart, 1989; Times, 1990). The need for developing these traits is best summarized by the social psychologist Uri Bronfenbrenner (1979):

No society can sustain itself unless its members have learned the sensitivities, motivations, and skills involved in assisting and caring for other human beings. Yet the school, which is carrying the primary responsibility for preparing young people for effective participation in adult life, does not, at least in American society, give high priority to providing opportunities in which such learning could take place (p. 8).

Research suggests that the environment can influence the nurturing of these traits, (Battistich, Watson, Solomon, Schaps \& Solomon, 1991; Berman, 1997; Danish \& Kagan, 1971; Zahn-Waxler \& Radke-Yarrow, 1982) and the indications are that as a society, this must become an imperative.

\section{Physical and Mental Energy}

Physical and mental energy are more difficult to define, and are best understood in the context of several related factors that have been discussed in the research literature. The nature of charisma, defined often as nonverbal emotional expressiveness and the ability to inspire followers with ad- 
miration (Lindholm, 1990), implies a high level of physical and mental energy. Curiosity, or inquisitiveness, also manifests in high levels of energy or intensity. In her study of eminent older women, Reis (1995) also found a sense of vitality and energy to be an essential personal characteristics.

The importance of this energy level to creative production has been identified and described by several different theorists. John-Steiner (1997) states: "Creativity requires a continuity of concern, an intense awareness of one's active inner life combined with sensitivity to the external world ... intensity is then the one universal given in this account of creative thinking" (p. 219). Dabrowski (1977) identifies five specific areas of sensitivity that are described as over excitabilities. Some children exhibit intense energy levels in one or more of these five areas: psychomotor, intellectual, emotional, imaginational, and sensual. These can often be identified and misinterpreted by teachers and counselors in the labeling of children as hyperactive, impulsive, or unable to sustain attention (Baum, Olenchak, \& Owen, 1998). These traits can be challenging for adults dealing with young people, but such traits when guided and nurtured, can lead to successful accomplishments, and when ignored can often lead to pathology. Many of the great leaders and producers of history (e.g., Leonardo de Vinci, Albert Einstein, Margaret Senger, Booker T. Washington) displayed such intensities. This has lead psychologists to also question whether the outer limits of mental stability or even mental health are prerequisites for creative behavior (John-Steiner, 1997). In the search to nurture creative behavior, the thinking should be perhaps to value and guide some of these intensities rather than try to label and remediate them.

The potential for both positive and negative manifestation permeates the literature in the work on charisma as well. Charismatic figures are represented by historical theorists such as Nietzshe and Weber to be more vivid than ordinary mortals; they appear to exist in an altered and intensified state of consciousness that is outside of ordinary emotional life (Lindholm, 1990). The power of a charismatic leader is absolute and can be used for positive or negative ends. Examples are seen in Martin Luther King, and John F. Kennedy on one end of the spectrum, and Adolph Hitler, Charles Manson, and David Koresh on the other. Instruments have been developed to measure charismatic tendencies based on self- report (Friedman, 1980), yet much work needs to be done not only in measuring and developing charismatic traits, but in developing moral courage and sensitivity to human concerns so that these abilities can be used for societal good and advancement rather than, as history has shown can often be the case, for personal power and even crimes against humanity.

Curiosity or inquisitiveness can be yet another component of physical and mental energy, fueling one's desire for learning even when the application of knowledge is not readily apparent. This suggests an investigation of self-determination theory and the concept of intrinsic motivation (Ryan \& Deci, 2000). Findings show that these are related to three psychological needs: competence, autonomy, and relatedness. When these conditions are met, the result is increased motivation and mental health and when hindered, lead to diminished well-being. Several scales measuring inquisitiveness include items that emphasize the desire to explore many topics and learning for learning's sake (Gottfried, 1982; Kreitler, Kreitler \& Zigler, 1974; Naylor, 1981). Extensive curiosity can lead to dangerous behaviors as well, yet studies also show a more predominant positive 
relationship between curiosity and creativity (Padhee \& Das, 1987). Identification of social or environmental factors that nurture these traits concerns many researchers. Non-punitive environments open to exploration rather than those which exert excessive control, provide low levels of challenge, and lack connectedness prove to allow for optimizing potential in the expression of physical and mental energy (Berman, 1997; Ryan \& Deci, 2000). Finally, the first of the seven da Vincian principles representative of that energetic icon is "curiosita" - an insatiably curious approach to life and an unrelenting quest for continuous learning (Gelb, 1998).

\section{Vision/Sense of Destiny}

Vision/Sense of Destiny is the least researched component of Operation Houndstooth, and yet we know from the history of civilization that persons with vision and a sense of destiny have truly made the modern world. Although there is a paucity of literature directly associated with destiny, the life histories of individuals eminent in their respective fields strongly suggest that vision and destiny are integral to the development of extraordinarily high levels of performance and success. Examples include Albert Einstein, Rachel Carson, and Martin Luther King, Jr. Individuals possessing a sense of vision or destiny are apparent not only in retrospect but during early development. Consider the boy who is currently youth spokesperson for the World Centers of Compassion for Children, an organization to which he is devoted and for which he has traveled, encouraging education and policy for global non-violence (Silverman, Roeper, \& Smith, 2000). While identification and description of the characteristics setting these individuals apart from simple performance or success is difficult, the manifestation of those characteristics is quite obvious. Given the difficulty in identifying and describing characteristics that highlight the contributions and level of commitment of such individuals, it is not surprising that quantifying and defining those characteristics are far from accomplished.

Despite the dearth of research literature in these areas, possible components of these factors seem to be emerging from a few well-researched areas of psychology and education. These include achievement motivation, competence motivation, locus of control, intrinsic motivation, self-determination theory, and self-regulation theory (Ambrose, 2000; Rea, 2000; Rotter, 1966; Ryan \& Deci, 2000; Schwartz, 2000; Wicker, Lambert, Richardson, \& Kahler, 1984; Williams, 1998; Wong \& Csikszentmihalyi, 1991). Erikson (1964) spoke of the will as the unbroken determination to exercise free choice as well as self-restraint. He also spoke of purpose as the courage to envision and pursue valued goals, and of competence as that which eventually becomes "workmanship." Almost all the research on gifted contributors to all walks of life points out that eminent individuals possess an urge not to settle, conform, or become complacent. This research consistently recognizes the task commitment of these individuals for continuing their efforts, sometimes under the most adverse circumstances.

A sense of direction falls under the vision and sense of destiny component in Operation Houndstooth as does a sense of power to change things. In research about gifted women Reis $(1995,1998)$ found that a sense of destiny characterized those who achieved eminence. Of course, finding literature directly addressing these subcomponents has been as futile as the searches pertaining to vision and destiny. However, if one pulls these subcomponents into the mix of motivation theories, 
self-determination, and locus of control, an intriguing thought experiment is possible a mental exercise that may lead to the most effective method for defining and describing these non-intellective factors.

If we can assume that those individuals with high measures of internal locus of control are likely to have high measures of some combination of curiosity, personal interest, and achievement motivation, then we can infer that having a highly internal locus of control may lead that individual to a sense of purpose. With a sense of purpose, self-determination would seem reinforced, perhaps magnified, leading to a sense of direction. As an individual begins to possess that sense of direction, he or she will be more apt to develop a vision for his or her future. With a sense of vision, comes the feeling that one has the power to make a difference (a sense of power to change things), and once that is in place, it seems a natural conclusion that a sense of destiny arises.

In his article on optimal motivation, Rea (2000) offers a formula-like definition for achievement motivation. Achievement motivation, as he presents it, is comprised of expectancy, value, and affect, which, when optimized, produce optimal achievement evidenced as Csikszentmihalyi's concept of flow. Rea relates serious fun to flow, and says that students are optimally motivated to develop their talents when in flow because their physical and mental well-being and their performance levels are high. If Rea is correct that flow (seen as optimal achievement motivation) is the ideal situation for talent development, and if the thought experiment above is accurate in including achievement motivation (along with intrinsic motivation, self-determination, and internal locus of control) as a foundational precursor to vision and destiny, then one can begin to illustrate how talent development relates to the co-cognitive factors and their subcomponents described herein.

\section{The Role of Gifted and General Education}

The history and culture of mankind can be charted to a large extent by the creative contributions of the world's most gifted and talented men and women. Advocates for special services for the gifted regularly invoke the names of persons such as Thomas Edison, Marie Curie, Jonas Salk, Isodora Duncan, and Albert Einstein as a rationale for providing supplementary resources to improve the educational experience of potentially gifted young people. If we assume that it has, indeed, been these people who have created the science, culture, and wisdom of centuries past, then it is also safe to assume that persons who are the stewards and nurturers of today's potentially able young people can have a profound effect on shaping the values and directions toward which our society's future contributors of remarkable accomplishments devote their energies. Such stewardship is an awesome responsibility, and yet it has some intriguing overtones, because the names of persons who will be added to the lists of Edisons and Einsteins are in our homes and classrooms today. It is also important to point out that this stewardship does not rest solely with teachers who are directly responsible for gifted programs. Melanie did, in fact, do her work as part of a special program for the gifted, but many other instances of creative productivity and problem solving by young people are guided by teachers in general education programs. In spite of our best efforts to identify students for special programs, predicting who will be our most gifted contributors is still a very inexact science. What is even more significant, so far as our work on Operation Houndstooth is concerned, is that by expanding the conception of giftedness beyond the traditional high scoring 
test-takers and good lesson-learners paradigm, we will find a rich source of potentially gifted contributors in a broad and diverse population of non-selected students as we find in students traditionally selected for gifted programs. Said another way, does anybody really care about the test scores or grade point average of people like Melanie or Martin Luther King, Jr?

\section{Are the Goals of Operation Houndstooth Realistic?}

There have been times in the history of civilization when the zeitgeist has resulted in elevating a society's values toward concerns that emphasize the production of social capital. The focus on democracy in Ancient Greece, the ascendancy of the arts during the Renaissance, and the elevation of man as a logical and rational thinker during the Reformation are examples of times when entire cultures and societies brought new ways of thinking to bear on issues that enriched the lives of people. And even in our own country, there were times when our culture placed a higher value on a sense of community and the dedication of individual and group efforts toward improvement of the greater good. In 1830, Alexis de Tocqueville, the French philosopher and celebrated commentator on our emerging democracy, wrote about the need and desire for civil associations of all kinds on the parts of Americans who, he observed, worked together with their fellow citizens toward common goals. "Americans of all ages, all conditions, and all dispositions constantly form associations ...," he noted. "Nothing in my opinion is more deserving of our attention than the intellectual and moral associations of America" (de Tocqueville, 1945, p. 109). De Tocqueville went so far as to say that the key to making democracy work in America was the propensity of our ancestors to form all kinds of civic associations to view the building of community as important as personal success and prosperity. If, as studies have shown, self-interest has replaced some of the values that created a more socially conscious early America, and if the negative trends of young people's over indulgences and disassociations are growing, then we must ask if there is a role that schools can play in gently influencing future citizens and, especially future leaders, toward a value system that assumes greater responsibility for the production of social capital? Modern society is barraging our young people with messages that emphasize fast-paced life, material gain, selfishness, and rampant consumerism.

Ask anyone, especially professionals, how their job is going and the almost universal answer is about how busy they are! I recently interviewed a very successful executive who described 18hour workdays, sometimes seven days a week. It has become a mark of status to be busy, and people literally boast about working 60 to 80 hours per week, or about having to eat lunch at their desk and work on their laptop or cell phone while using the treadmill. This executive made clear his material success as he boasted about his cars and boats and new home with a 4-car garage, but then he explained, "I have a ski house in the mountains and a summer house on the beach, but, ya know, I never have time to use either one of them!"

Everything is going faster: the average sound bite by persons running for U. S. President is less than thirty seconds and the so-called presidential debates are nothing more than strings of these sound bites. We've traded in-depth stories in the New York Times and Atlantic Magazine for the six o'clock news and USA Today, and we've replaced reading a good biography with a quick trip through People Magazine. Fed Ex, cell phones, e-mail, round-the-clock stock trading, and drive 
through Egg McMuffins are the way many people run their lives. And we also have speeded up other things that should be important reflections of the quality of life. Recent studies have shown that we spend less than 31 minutes a day caring for our children and seven minutes caring for our pets. Each day adult college graduates spend16 minutes or less per day reading non-work related material, and young married couples spend an average of four minutes a day engaged in anything that in polite company we might call romantic encounters! Our fast paced world and scientific technology have created the mechanisms of production and consumerism that define the present American way of life, but they have also created a mind-set that sees the world as an endless resource for consumption that has contributed to a rapidly growing world ecological crisis. Nowhere is this mind-set more evident than in the life styles of young people. And who can blame them when they are subjected to an educational system that focuses mostly on skills that will give them a competitive advantage in the marketplace and a commercial media establishment that barrages young people with constant messages about consumption and material gain?

Recently, while recuperating from surgery, I began to notice the messages that are flashed across the bottom of the television screen on a continuous basis -- seven days a week, 24 hours a day on some channels. Instant updates on the Dow Jones Industrial Average, NASDAQ, and Standard and Poors. And the home shopping channels bombard viewers with an endless array of products that feed the mainstream materialism so rampant in our culture. I began to fantasize about different kinds of messages that might convey to our society, and especially to our young people, some of the things that can influence a more diverse set of values in the Twenty-first Century. Is it beyond our vision as educators to imagine a role for schools that can influence the future leaders of the new century in ways that would help them acquire values that result in the production of social capital as well as material consumption and economic gain? Can a vision about the role of education include creating future political leaders who place fairness and kindness and social justice ahead of power, control, and pandering to special interest groups? And can we create the future CEOs of automobile and energy companies who are as committed to safety and emission control as they are to shareholder's profits, sexier cars, and the corporate bottom line? Could some of the endless pitches for commercial products at least be interspersed with advocacy for more time with our children, a greater tolerance for diversity, and more concern for the rapid depletion of the Earth's resources? Can the strips that flow across the bottom of our television screens carry messages that relate to gross national happiness as well as gross national product? It is intriguing to think that the men and women who will decide the content of these messages are the boys and girls who are in our classrooms today.

The general goal of this work is to infuse into the overall process of schooling experiences related to the Houndstooth components that will contribute to the development of wisdom and a satisfying lifestyle. It would be naive to think that a redirection of educational goals can take place without a commitment at all levels to examine the purposes of education in a democracy. It is also naïve to think that experiences directed toward the production of social capital can, or are even intended to replace our present day focus on material productivity and intellectual capital. Rather, this work seeks to enhance the development of wisdom and a satisfying lifestyle that are paralleled by concerns for diversity, balance, harmony, and proportion in all of the choices and decisions that 
young people make in the process of growing up. What people think and decide to do drives some of society's best ideas and achievements. If we want leaders who will promote ideas and achievements that take into consideration the components we have identified in Operation Houndstooth, then giftedness in the new century will have to be redefined in ways that take these co-cognitive components into account. And the strategies that are used to develop giftedness in young people will need to give as much attention to the co-cognitive conditions of development as we presently give to cognitive development.

Although there is no silver bullet or institutional fix for infusing these components into the curriculum or creating a greater awareness about the need to produce more social capital, there are things that lend feasibility to this endeavor. First, the entire positive psychology movement is growing in popularity and promises to enhance research endeavors of the type we are pursuing. Second, already completed research in psychology, sociology, and anthropology clearly indicate that these co-cognitive traits can be assessed (at varying levels of precision) and that the environment in general, and schooling in particular, can nurture and influence the components we have identified in Operation Houndstooth. Third, economists have pointed out the benefits of a reciprocal relationship between material and social capital, and many social, political, spiritual, and educational commentators have indicated that nurturing these traits must become an imperative.

My colleagues and I are only in the early stages on this path toward once again attempting to expand the definition of giftedness. We believe that an expanded definition will not only help us understand the unique contributions of persons who have used their talents to make the world a better place, it will also help us to extend supplementary opportunities and services to potentially able young people who have been overlooked because of the overemphasis of cognitive traits in the identification of giftedness. Each area of inquiry brings us closer to understanding the complexity of the concepts, identifying promising practices and assessment techniques that are being used in present and future scientific studies, and bringing this message forward to interested educators. While the whole notion of changing the big picture seems awesome and overwhelming, the words of Margaret Mead remind us that it can be done: "Never doubt that a small group of thoughtful, committed citizens can change the world...indeed, it is the only thing that ever does."

\section{References}

Amabile, T. (1983). The social psychology of creativity. New York: Springer Verlag.

Ambrose, D. (2000). World-view entrapment: Moral-ethical implications for gifted education. Journal for the Education of the Gifted, 23(2), 159-186.

Aspinwall, L. G., \& Brunhart, S. M. (2000). What I do know won't hurt me: Optimism, attention to negative information, coping, and health. In J. E. Gillham (Ed.), Laws of life symposia series. The science of optimism and hope: Research essays in honor of Martin E. P. Seligman (p. 163-200). Philadelphia: Templeton Foundation Press.

Aspinwall, L.G., \& Richter, L. (1999). Optimism and self-mastery predict more rapid disengagement from unsolvable tasks in the presence of alternatives. Motivation and Emotion, 23(3), 221-245.

Battistich, B., Watson, M., Solomon, D., Schaps, E., \& Solomon, J. (1991). The child development project: Program for the development of prosocial character. In W. Kurtines and J. Gewirtz 
(Eds.), Handbook of moral behavior and development, Volume 3: Application (pp. 1-34). Hillsdale, NJ: Lawrence Erlbaum.

Barns, H. (1979). History teaching - dramatic art. In E. Piening \& N. Lyons (Eds.), Education as an art. New York: The Rudolf Steiner School Press.

Baum, S. M., Olenchak, F. R., \& Owen S. V. (1998). Gifted students with attention deficits: Fact and/or fiction? Or, can we see the forest for the trees? Gifted Child Quarterly, 42(2), 96-104.

Berman S. (1997). Children's social consciousness and the development of social responsibility. Albany, NY: State University of New York Press.

Bronfenbrenner, U. (1979). The ecology of human development. Cambridge, MA: Harvard University Press.

Chang, E.C. (Ed.). (2001). Optimism and pessimism: Implications for theory, research, and practice. Washington, DC: American Psychological Association.

Chlopan, B. E., McCain, M. L. Caronell, J. L. \& Hagen, R. L. (1985). Empathy: Review of available measures. Journal of Personality and Social Psychology 48, 3 635-653.

Csikszentmilhalyi, M. (1990). Flow: The psychology of optimal experience. New York: HarperCollins.

Csikszentmihalyi, M. (1996). Creativity: Glow and the psychology of discovery and invention. New York: HarperCollins.

Dabrowski, K., \& Piechowski, M. M. (1977). Theory of levels of emotional development (Vol. 1 \& 2). Oceanside, NY: Dabor Science.

Danish, S. J. \& Kagan, N. (1971). Measurement of affective sensitivity: Toward a valid measure of interpersonal perception. The Journal of Counseling Psychology, 18(1) 51-54.

de Tocqueville, A. (1945). Democracy in America (Vol. 2). New York: Alfred A Knopf.

Eisenberg, N., \& Miller, P. A. (1987). The relation of empathy to prosocial and related behaviors. Psychological Bulletin, 101(1), 91-119.

Eisenberg-Berg, N. (1979). Development of children's prosocial moral judgment. Developmental Psychology, 15(2), 128-137.

Eliot, C. W. (Ed) (1909). The Harvard classics, New York: Collier \& Son.

Erikson, E. H. (1964). Insight and responsibility: Lectures on the ethical implications of psychoanalytic insight. New York: W.W. Norton \& Company, Inc.

Feshback, N. D., \& Hoffman. M. L. (1978, April). Sex differences in children's reports of emotionarousing situations. Paper presented in D. McGuiness (chair), Symposium at Western Psychological Association meetings, San Francisco.

Fowler, D. (1990). Democracy's next generation. Educational Leadership, 48(3), 10-15.

Fredrickson, B. (2000, March 7). Cultivating positive emotions to optimize health and well-being. Prevention and Treatment [On-line], 1-26. Available: http://journals.apa.org/prevention/volume3/pre0030001a.html

Friedman, H. S. (1980). Understanding and assessing nonverbal expressiveness: The affective communication test. Journal of Personality and Social Psychology, 39(2), 333-351.

Gagné, F. (1985). Giftedness and talent: Reexamining a reexamination of the definitions. Gifted Child Quarterly, 29, 103-112.

Gardner, H. (1983). Frames of mind: The theory of multiple intelligences. New York: Basic Books.

Gelb, M. J. (1998). How to think like Leonardo da Vince. New York: Delacorte Press.

George, P. G., \& Scheft, T. (1998). Children's thoughts about the future: Comparing gifted and nongifted students after 20 years. Journal for the Education of the Gifted, 21(2), 224-239.

Gottfried, A. E. (1982). Children's academic intrinsic motivation inventory. Princeton, NJ: Educational Testing Service.

Gove. F. L. \& Keating, D. P. (1979). Empathic role-taking precursors. Developmental Psychology, 15 (6) 594-600. 
Hart Research Associates (1989). Democracy's next generation: A study of youth and teachers. Washington DC: People for the American Way.

John-Steiner, V. (1997). Notebooks of the mind: Explorations of thinking. New York: Oxford University Press.

Kaufman, F. (2000). Gifted education and romance of passion. Communicator 31(3), 1.

Kogan, M. (2000). Teaching truth, beauty, and goodness. [An interview with Howard Gardner]. Monitor on Psychology, 31(12), 66-67.

Kreitler, S., Kreitler, H., \& Zigler, E. (1974). Cognitive orientation and curiosity. British Journal of Psychology, 65, 43-52.

LaBonte, R. (1999). Social capital and community development: Practitioner emptor. Australian and New Zealand Journal of Public Health, 23(4), 430-433.

Larson, R. W. (2000). Toward a psychology of positive youth development. American Psychologist, 15(1), 170-183.

Lindholm, C. (1990). Charisma. Cambridge, MA: Basil Blackwell.

MacKinnon, D. W. (1978). In search of human effectiveness. Buffalo, NY: Creative Education Foundation, Inc.

Maslow, A. (1954). Motivation and personality. New York: Harper.

Mehrabian, A., \& Epstein, N. (1972). A measure of emotional empathy. The Journal of Personality, 40(4), 525-543.

Mönks, F. J. (1991). Kann wissenschaftliche argumentation auf aktulität verzichten? (Are scientific arguments dispensable in the discussion on identification of the gifted?) Zeitschrift für Entwicklungspsychologie und Pädagogische Psychologie, 23, 232-240.

Moon, S. M. (2000, May). Personal talent: What is it and how can we study it? Paper presented at the Fifth Biennial Henry B. and Joycelyn Wallace National Research Symposium on Talent Development, Iowa City, IA.

Naylor, F. D. (1981). Melbourne curiosity inventory. Australian Psychologist, 16(2), 172-183.

Padhee, B., \& Das, S. (1987). Reliability of an adapted curiosity scale. Social Science International 3(2), 27-30.

Peterson, C. (2000). The future of optimism. American Psychologist, 55(1), 44-55.

Portes, A. (1998). Social capital: Its origins and applications in modern sociology. Annual Review of Sociology, 24, 1-24.

Putman, D. (1997). Psychological Courage. Philosophy, Psychiatry, E Psychology, 4(1), 1-11.

Putnam, R. (1993). Making democracy work: Civic traditions in modern Italy. Princeton: Princeton University Press.

Putnam, R. (1995). Bowling alone: America's declining social capital. Journal of Democracy, 6(1), 6578 .

Rea, D. W. (2000). Optimal motivation for talent development. Journal for the Education of the Gifted, 23(2), 187-216.

Reis, S.M. (1995). Older women's reflections on eminence: Obstacles and opportunities. Roeper Review, 18(1), 66-72.

Reis, S.M. (1998). Work left undone: Choices and compromises of talented females. Mansfield Center, CT: Creative Learning Press, Inc.

Renzulli, J. S. (1977). The Enrichment Triad Model: A guide for developing defensible programs for the gifted and talented. Mansfield Center, CT: Creative Learning Press.

Renzulli, J. S. (1978). What makes giftedness? Re-examining a definition. Phi Delta Kappan, 60, 180184.

Rotter, J. B. (1966). Generalized expectancies for internal versus external control of reinforcement. Psychological Monographs, 81(1), 1-28. 
Ryan, R. M. \& Deci, E. L. (2000). Self-determination theory and the facilitation of intrinsic motivation, social development, and well-being. American Psychologist, 55, 1, 68-78.

Scheier, M. F., \& Carver, C. S. (1985). Optimism, coping, and health: Assessment and implications of generalized outcome expectancies. Health Psychology, 4, 219-247.

Schwartz, B. (2000). Self-determination: The tyranny of freedom. American Psychologist, 55(1), 7988.

Seligman, M. E. P. (1991). Learned optimism. New York: Knopf.

Seligman, M. E. P, \& Csikszentmihalyi, M. (2000). Positive psychology. American Psychologist, 55(1), 5-14.

Seligman, M.E.P., Reivich, K., Jaycox, L., \& Gillham, J. (1995). The optimistic child. New York: Houghton Mifflin.

Silverman, L., Roeper, A., \& Smith, G. (2000, November). A child shall lead them: Children for nonviolence. Paper presented at the meeting of the National Association of Gifted Children, Atlanta, GA.

Sternberg, R. J. \& Davidson, J. E. (1986). Conceptions of giftedness. New York: Cambridge University Press.

Stipek, D. J., Lamb, M. E., \& Zigler, E. F. (1981). OPTI: A measure of children's optimism. Educational Psychological Measurement, 41, 131-143.

Tannenbaum, A. J. (1986). Giftedness: A psychosocial approach. In R.J. Sternberg \& J.E. Davidson (Eds.), Conceptions of giftedness. New York: Cambridge University Press.

Tiger, L. (1979). Optimism: The biology of hope. New York: Simon \& Schuster.

Times Mirror Center for the People and the Press (1990). The age of Indifference: A study of young Americans and how they view the news. Washington DC: Author.

Underwood, B., \& Moore, B (1982). Perspective-taking and altruism. Psychological Bulletin, 91, 143173.

Wicker, F. W., Lambert, F. B., Richardson, F. C., \& Kahler, J. (1984). Categorical goal hierarchies and classification of the human motives. Journal of Personality, 52(3), 285-305.

Williams, J. (1998). Self-concept -performance congruence: An exploration of patterns among highachieving adolescents. Journal for the Education of the Gifted, 21(4), 415-422.

Wong, M. M., \& Csikszentmihalyi, M. (1991). Motivation and academic achievement: The effects of personality traits and the quality of experience. Journal of Personality, 59(3), 539-574.

Zahn-Waxler, C., \& Radke-Yarrow, M. (1982). The development of altruism: alternative research strategies. In N. Eisenberg-Berg (Ed.), The development of prosocial behavior (pp. 109-37). New York: Academic.

\footnotetext{
Note to Interested Readers

Material about Operation Houndstooth is being shared through presentations and postings on our web site and we are developing an ongoing database that will make methods and materials for co-cognitive development available to educators and parents. There are many ways in which interested persons can become involved in our research and I invite these readers to visit the Operation Houndstooth section of our web site [www.gifted.uconn.edu] where they can share their experiences and communicate their interest in possible research and field test opportunities.
} 